\title{
SH3KBP1 Gene
}

National Cancer Institute

\section{Source}

National Cancer Institute. SH3KBP1 Gene. NCI Thesaurus. Code C132140.

This gene is involved in the regulation of protein-protein interactions in signaling pathways. 